\title{
Yrityksiin kohdistuvien julkisten sääntelyvaikutusten arviointi: Neo-institutionaalinen tutkimus kontekstista, kansainvälisistä vaikutteista ja kotimaisista kokemuksista
}

\author{
Pertti Ahonen, Petri Uusikylä \& Riikka Sievänen
}

\begin{abstract}
Regulatory impact assessment (RIA) has an established place in the European Union and its member states. This article considers evolving Finnish ex ante RIA concerning certain regulatory costs to firms. Drawing upon a neo-institutional theoretical framework and proposing three generally oriented hypotheses we received the following results. (1) The rationality of the evolving Finnish ex ante RIA of selected administrative regulatory costs to firms gives rise to issues given the low implementation rate of the general natonal RIA guidelines. (2) Reference to the ex ante RIA of regulatory costs to firms in other countries has served the legitimation of preferred procedures in Finland rather than offers solid evidence on the rationality of the foreign procedures. (3) Without a stronger contextualization of the evolving Finnish ex ante RIA of regulatory costs to firms its procedures risk adverse effects because of their confined scope, the uneven quality of their input data, and their weak connections to the general national ex ante RIA. These results suggest the redesign of the Finnish RIA to take better into account the institutional, political, historical and cultural characteristics of governance in this country.
\end{abstract}

Keywords: regulatory impact assessment, public policy evaluation, public policymaking, lawmaking, legal policy, deregulation

\section{JOHDANTO}

Sääntely (regulation) muodostaa laajan tutkimusalueen, jonka erittelytarve on huomattava myös aihepiiriä hallinneiden oikeustieteiden ja taloustieteiden ulkopuolella. Tilaa on myös empiiriselle hallinnon ja politiikan tutkimukselle, jota artikkelimme edustaa. Suomessa keskeisin osa sääntelyä on lakisääteistä tai perustuu epäsuoremmin lakiin. Sääntelyä toteutuu julkista valtaa käytettäessä, silloin kuin yksityisen toiminnan instituutiopuitteet ovat lakisääteiset, verovaroista kustannetun julkisen talousarviorahoituksen perusteella tai yhdistelmänä verojen, verotukien, maksujen sekä maksupoikkeusten ja -helpotusten yhteisvaikutuksia. Julkisen vallan käyttö sääntelyssä koostuu kielloista, toimintojen monopolisoinnista julkisyhteisöille tai toimiluvan haltijoille tai toimintojen luvan, ilmoituksen, tarkastuksen tai raportoinnin alaisuudesta. Sääntelyn instituutiot ja käytännöt muodostuvat pääasiassa maan hallituksen ja sen alaisen asiantuntijahallinnon aloitteellisuuden perusteella eduskuntapuolueiden ja intressiryhmien vaikuttaessa vahvasti taustalla.

Euroopan unionin jäsenmaana Suomea sitovat kansallisen lainsäädännön ohella EU-lainsäädäntö sekä EU:n jäsenmaidensa puolesta solmimat kansainväliset sopimukset. Suomi on jäsen myös OECD:ssa, joka vailla norminantovaltaa vahvistaa jäsenmaistaan juontuvia ideoita noissa maissa sekä valikoiden tähdentää kansainvälisesti kierteleviä ajatuksia siitä, millaiset ratkaisut olisivat suotavia (Alasuutari \& Rasimus 2009, De Francesco 2013). Lisäksi Suomessa seurataan tapahtumia muissa maissa 
ja omaksutaan vaikutteita. Kontekstin ja kansainvälisten vaikutteiden rajoissa vallitsee kansallista pelivaraa puntaroitaessa vaihtoehtoisten ratkaisujen suotavuutta, käynnistettäessä muutoshankkeita ja pantaessa toimeen päätöksiä (Radaelli 2005). Tarkentaen tutkimustarvetta koskevaa tulkintaamme korostamme yritysten vaikutusta talouselämässä muotoilemme tutkimuskysymyksemme seuraavasti: Millaiset ovat konteksti, kansainväliset vaikutteet sekä pyrkimykset, perustelut ja kokemukset julkisen sääntelyn yrityksille aiheuttamien kustannusten laskennassa ja arvioinnissa Suomessa?

Artikkelimme teoreettisena tarkoituksena on koetella muotoilemiamme laaja-alaisia hypoteeseja. Ne nivoo yhteen neo-institutionalistinen teorianmuodostus. Mikäli hypoteesijoukkomme kokonaisuus tuntuu vieraalta, suosittelemme perehtymistä juuri neo-institutionalismiin. Hyvä perusteos on esimerkiksi Lowndesin ja Robertsin (2013) kirja toiselle kymmenelle nousevasta joukosta neo-institutionalismin suuntauksia. Hypoteesimme koskevat empiiristä tutkimuskohdettamme, joka koostuu julkisen lakiperusteisen sääntelyn yrityksille aiheuttamien kustannusten arvioinnista Suomessa. Neoinstitutionalismissa on yleisesti ottaen kysymys sen erittelystä, miten viralliset ja epäviralliset instituutiorakenteet, säännöt, normit ja kulttuurit ehdollistavat niiden vaikutuspiiriin sijoittuvien toimijoiden valintoja ja muita toimia. Käytännölliseltä kannalta artikkelimme nostaa esiin neo-institutionalisesta näkökulmasta korostuvia puutteita tutkimassamme arvioinnissa.

Sana "arviointi" on suomen kielessä monikäsitteinen. Se tarkoittaa tosin usein samaa kuin englannin kielen evaluation (Alkin 2012, Ahonen 2015). Sanalla käännetään kuitenkin myös englannin assessment. Julkiseen sääntelyyn (regulation; ks. Lodge \& Wegrich 2012) kohdistuva regulatory impact assessment (RIA) suomennetaan "sääntelyvaikutusten arvioinniksi", mikä luo mielikuvaa menettelyistä, jotka läheisesti rinnastuvat arviointiin merkityksessä evaluation. Joskin evaluationilla ja RIA:lla on leikkausalueita, huomattavalla osalla edellisestä kirjoitetusta (ks. esim. Alkin 2012) on vähän jälkimmäisen kanssa (ks. esim. Dunlop \& Radaelli 2016).

Arviointialalta sekä merkityksessä evaluation että assessment puuttuu yleinen, yhtenäinen ar- viointiteoria, theory on evaluation/theory on assessment, joka kelpaisi kehykseksi tutkimukselle kohteena arvioinnin tiedonhankinta, analysointi, arviointikriteerien soveltaminen, raportointi ja arviointitulosten hyväksikäyttö. Arviointialan teorianmuodostuksen pääkohteina ovat sen sijaan arvioinnin yksittäiset kohdealueet, jolloin teoriat edustavat lajia theories in evaluation/ theories in assessment. Tutkimuksemme kannalta olisi kategoriavirhe, jos olisimme pyrkineet rakentamaan sen oikeudellisen tai taloudellisen sääntelyn teorioiden varaan, sillä kysymys olisi ollut teorioista lajityyppiä "in" eikä "on". Jälkimmäiset teoriat paikannamme arviointialaa laajemmalta alueelta, neo-institutionalismin piiristä. Tarkoituksemme on se, että osa tutkimuksemme kontribuutioita perustuisi juuri "on"-perspektiivin soveltamiseen. Tästä seuraa tutkimuksemme meta-analyyttinen luonne, josta aiheutuu, ettei aivan suoraan esikuvallista aikaisempaa tutkimusta ole käytettävissä. Claudio Radaellinkin (2005) tutkimus poliittisen kontekstin vaikutuksesta sääntelyvaikutusten arviointiin kohdistuu arvioinnin omaksumiseen toisin kuin artikkelimme. Tutkimuksellemme välillisesti relevanttia aikaisempaa tutkimusta löytyy runsaasti, kuten lähdeluettelo osoittaa.

\section{TEOREETTISET LÄHTÖKOHDAT JA TUTKIMUSHYPOTEESIT}

Monet yhteiskuntatutkimuksessa tärkeistä metodologisista jaotteluista lepäävät sovinnaisääntöjen perustalla. Tutkimuksemme luonnetta selventää tietty kolmijako. Sen mukaan tutkimus voi edetä konfirmatoriseen tapaan asettaen kohdennettuja hypoteeseja, jotka pyritään todentamaan tilastollisesti testaamalla (ks. esim. Reynolds 1998), tiettyyn eksplorativiseen tapaan asettaen laaja-alaisia hypoteeseja, joiden paikkansapitävyyden tutkimus varmistaa pehmeämmillä kuin testaukseen perustuvilla tavoilla (ks. esim. Quaglia 2019), tai toiseeen eksploratiiviseen tapaan asettaen vain tutkimuskysymyksiä, joihin tutkimus etsii vastauksia (ks. esim. Stark 2019). Sekä konfirmatorisessa että hypoteeseja asettavassa eksploratiivisessa tutkimuksessa muotoillaan usein tutkimuskysymys tai useampi hypoteesien muotoilun edellä. Tutkimuksemme edustaa eksploratiivisen tutkimuksen hypoteeseja testaavaa lajia. 
Kuten esitimme artikkelimme ensimmäisessä jaksossa, sovellamme theories on evaluation/ theories on assessment -näkökulmaa sen sijaan, että rakentaisimme teorioille arvioinnin eri kohteista, theories in evaluation/theories in assessment. "On"-näkökulmasta on oleellista se, että sääntelyvaikutusten arvioinnilla on taloudellinen, poliittinen, kansallinen, kulttuurinsa ja muut kontekstinsa eli kokonaisyhteytensä. Korostamme kokonaisyhteyksistä erityisesti Suomen voimassa olevia lainsäädännön vaikutusten arviointiohjeita (OM 2007) ja niiden tosiasiallisen toimeenpanon tasoa (Pakarinen ym. 2011, Rantala 2010). Neo-institutionaalisella kielellä ilmaisten ohjeet edustavat järkiperäisyyttä ( $\mathrm{ra}$ tionality) ja tarkentaen välineellistä järkiperäisyyttä (instrumental rationality). Tuon järkiperäisyyden tulisi toteutua siten, että keskenään yhteen sovittuisivat asetetut tavoitteet, niiden saavuttamista varten määritellyt keinot, keinojen käyttö sekä sekä tarkoittamattomien sivuvaikutusten kontrolli. Tällaista institutionaalista logiikkaa March ja Olsen (ks. esim. March \& Olsen 2009) kutsuvat seurausvaikutusten instituutiologiikaksi (logic of consequences). Heidän mukaansa esiintyy toinenkin tärkeä instituutiologiikkaa, soveliaisuuden instituutiologiikka (logic of appropriateness). Toinen logiikka perustuu konventioille eli sovinnaiskäytänteille, standardoiduille menettelytavoille, peukalosäännöille sekä ohjeellisille mittareille, indekseille tai kriteereille. Marchin ja Olsenin mukaan jälkimmäisen logiikan sääntelemänä määräytyy seurausvaikutusten logiikan asemesta usein se, mitä tapahtuu. Ensimmäinen tutkimushypoteesimme on:

Tutkimushypoteesi 1: Sääntelyn yrityksille aiheuttamien kustannusten arvioinnin kokonaisyhteyksinä sääntelyvaikutusten yleinen arviointi edustaa soveliaisuuden instituutiologiikkaa (logic of appropriateness) pikemmin kuin seurausvaikutusten instituutiologiikkaa (logic of consequences).

March ja Olsen (2009) eivät kiistä sitä, ettei seurausvaikutusten instituutiologiikka voisi vallita käytännössä. Kuitenkin niin he kuin muut neoinstitutionaaliset tutkijat ovat kiinnittäneet huomiota siihen mahdollisuuteen, ettei tuo logiikka olisi yksinomainen, ettei sillä olisi hallitsevaa asemaa tai ettei sitä edes sovellettaisi. Weyland (2007) tiivistää aikaisemmalle neo-institutionalistiselle tutkimukselle rakentaen kolme vaihtoehtoa seurausvaikutusten instituutiologiikalle:

1. Vaikka rationaalisuus instrumentaalisen rationaalisuuden mielessä sinänsä vallitsee, se esiintyy rajattuna rationaalisuutena (bounded rationality), jolloin tiedonhankinta uusia ratkaisuja etsittäessä ja alaltaan suppeaksi ja omaksutut ratkaisut poikkeavat vain rajoitetusti siitä, miten asiat ovat olleet siihen saakka (Cyert \& March 1963, Cohen, March \& Olsen 1973; alkujaan Simon 1947). Saattaisimme ajatella, etteivät ainakaan uuden suunnittelu, muutostyö ja uudistustoiminta voisi rutinoitua, Juuri niin kuitenkin usein käy, jolloin uudistustoiminta jää rajatusti rationaaliseksi (Brunsson 2009).

2. Määrätyt impulssit saatetaan esittää vaihtoehdottomiksi kuten luonnehdittaessa kansainvälisten organisaatioiden suosituksia tai ehdollisia uhkia ehdottomiksi ja muita vaihtoehtoja kuin puollettua vaihtoehtoa oudoiksi, heiveröisiksi ja oleellisia arvoja vaarantaviksi Hirschmanin (1991) "taantumuksen retoriikan" tapaan.

3. Muodollinen järkiperäisyys on kenties tavallista ja laajalle levinnyttä. Toisaalta sekään ei ole harvinaista, että parhaiksi esitetyt ratkaisut perustuvat esimerkillisiksi katsottujen kohteiden piirissä toteutettujen ratkaisujen jäljittelylle (emulation) ja institutionaalisen samanmuotoisuuden (isomorphism) etsinnälle. Tällöin on mahdollista, että viittauksia esimerkillisiksi korotetuissa kohteissa sovellettuihin ratkaisuihin käytetään siten, että pyritään legitimoimaan esikuvia muistuttavia ratkaisuja uusissa kohteissa, vaikka näytöt puuttuisivat jäljiteltyjen ratkaisujen rationaalisuudesta tai niiden tosiasiallisesta toimeenpanosta (Meyer \& Rowan 1977, Lee \& Strang 2006).

Toinen tutkimushypoteesimme saa seuraavan asun:

Tutkimushypoteesi 2: Sääntelyn yrityksille aiheuttamien kustannusten arviointi ei välttämättä rakennu vain välineelliselle järkiperäisyydelle tavoitteiden, keinojen ja sivuvaikutusten puntarointeineen toisiaan vasten. 
Arviointi voi perustua myös aikaisemmista vain rajoitetusti poikkeavien ratkaisujen toimeenpanoon, ehdollisten impulssien esittämiseen ehdottomiksi, määrättyjen menettelytapojen esittämiseen välttämättömiksi tai haluttujen ratkaisujen legitimointiin jäljittelyllä, joka kohdistuu esimerkillisiksi esitettyihin ratkaisuihin, jotka on pantu toimeen toisaalla.

Se mahdollisuus, ettei välineellinen järkiperäisyys vallitsisi ainakaan poikkeuksetta, tekee tarpeelliseksi selvittää, jääkö tuo järkiperäisyys vetoomuksiksi haluttujen ratkaisujen legitimoimiseksi sen sijaan, että muodollinen järkiperäisyys vallitsisi näyttöperusteisesti sen enempää jäljittelyn kohteissa kuin jäljittelyn harjoittajien toimintapiirissä. Asian tarkastelulle tarjoaa perustan neo-institutionaalisen tutkimuksen peruskäsitteistä järkiperäistetty myytti (rationalized myth, Meyer \& Rowan 1977, ks. myös esim. Schriewer 2009). Kuten perinteinen myytti, rationalisoitu myytti ylikorostaa kohteensa alkuperän legitiimiyttä. Perinteisen myytin alkuperä juontuu perinteisistä uskomuksista, joiden mukaan vaikkapa esi-isien henget vaativat kuivan kauden pitkittyessä sadetanssirituaalia, vaikkei ainoatakaan vesipisaraa ole koskaan saatu sadetanssin tuloksena putoamaan. Rationalisoidun myytin alkuperän muodostaa sinänsä välineellisesti rationaalinen tavoitteiden, keinojen ja sivuvaikutusten puntarointi toisiaan vastaan mutta ilman, että tuollainen puntarointi yltäisi näyttöperusteisuuteen. Esimerkiksi rationalisoidusta myytistä kelpaa rationaalinen järjestelmä tai metodi, joka tosin on saatettu muodollisesti voimaan, mutta jonka toimeenpano jää riittämättömäksi. Järjestelmän tai metodin avulla saavutettuja tuloksia ei kenties tosiasiassa käytetä tai tulokset osoittautuvat soveltumattomiksi päätöksenteossa joko lähtötietojen laatuongelmien johdosta, toimeenpanoasteen alhaisuuden vuoksi tai siksi, etteivät tulokset kohtaa päätöksenteon tietotarpeita. Kolmas tutkimushypoteesi muodostuu seuraavaksi:

Tutkimushypoteesi 3: Sääntelyn yrityksille aiheuttamien kustannusten arvioinnissa sekä sen metodeissa ja niiden sovelluksissa on korkeintaan vain joiltakin osin kysymys rationalisoinnista eli järkiperäistämisestä (rationalization) tavoitteiden asettamiseksi, keinojen määrittelemiseksi, keinojen yhdistelemiseksi tavoitteiden saavuttamiseksi ja sivuvaikutusten ottamiseksi huomioon. Rationalisoinnin ohella tai sille vaihtoehtoisesti voi olla kysymys järkiperäistetyistä myyteistä (rationalized myths) rationalisoinnin tähdennyksin, vaikka rationalisointi jää osin tai kokonaan toteutumatta.

\section{AINEISTOT JA METODIT}

Artikkelimme laatimiseksi ei ollut tarpeen kerätä uutta primaariaineistoa. Käytettävissämme olivat runsaat sekundaariaineistot. Me kirjoittajat olemme erilaisin kokoonpanoin osallistuneet kolmeen selvityshankkeeseen, joiden tuloksia olemme analysoineet uudelleen ja edelleen (Uusikylä \& Ahonen 2015, Tuominen-Thuesen ym. 2018, Rantala ym. 2018). Ottaen huomioon tämän olemme kiinnittäneet huomiota meidät kohteestamme etäännyttävän tutkimusotteen muodostamiseen. Tämä pyrkimys on vaikuttanut myös siihen, että olemme omaksuneet $r e$ search on evaluation -tutkimussuuntauksen sekä neo-institutionaalisen viitekehyksen. Käytettävissämme on ollut runsas aineisto, jonka erittelyn hyviin käytäntöihin kuuluu tähtääminen saturaatioon eli kyllästymispisteen saavuttamiseen siten, että aineiston hankintaa ja analysointia on jatkettu, kunnes uutta tietoa ei enää ole muodostunut (Silverman 2011, Fusch \& Ness 2015).

Tieteenfilosofisesti perustellun nykykäsityksen mukaan jo yksittäisen tapauksen analyysi voi tuoda ansiokkaasti esiin tutkitun ilmiön olennaiset piirteet ja ominaisuudet (ks. esim. Skocpol 1979, Alapuro 1988, Flyvbjerg 2006). Olemme artikkelissamme soveltaneet tapaustutkimuksen logiikkaa mutta ei ajanmukaisuutensa menettäneeseen tapaan tilastollisen yleistämisen logiikkaa mukaillen. Sen sijaan olemme ottaneet huomioon uudemmat yleistämisen logiikat eli analyyttisen yleistämisen (analytical generalization, Yin 2016), olosuhderiippuvaisen yleistämisen (contingent generalization, George \& Bennett 2006), mekanismiperusteisen yleistämisen (generalization by mechanism, Bengtsson \& Hertting 2014) sekä todennäköisyyspohjaisen yleistämisen (probabilistic generalization, Blatter \& Haverland 2012). Kunkin noista logiikoista 
mukaan jo yksikin tapaus voi tuoda esiin teoreettisesti merkittäviä tai muuten oleellisia tutkimuskohteen piirteitä. Empiirisen yleistämispyrkimyksen asemesta tutkijan on silloin, kun hän puntaroi aikaisemman tutkimuksen tulosten relevanssia uuden kohteen analyysille, selvitettävä kontekstien erot tutkimuskohteiden kesken. Vasta niin tehtyään hän voi sopeuttaa aikaisemman tutkimuksen tulosten pätevyysehtoja uusia tutkimuskohteita koskevien päätelmien muodostamiseksi.

\section{TUTKIMUSTULOKSET}

\section{Sääntelyn kohteilleen aiheuttamien kustannusten laskennan ja arvioinnin kokonaisyhteydet}

Suomessa säädösehdotusten vaikutusarviointiohjeissa arvioinnin ala on rikkeettömän kattava. Ohjeiden mukaan (OM 2007, 8, kursivoinnit alkuperäiset):

Vaikutuksia arvioitaessa tulee tarkastella niin hankkeen tavoiteltuja vaikutuksia ja hyötyjä kuin sen kustannuksia ja mahdollisia kielteisiä vaikutuksia. Arvioinnissa on myös pyrittävä tunnistamaan riskejä ja odottamattomia vaikutuksia.

Oikeusministeriön ohjeiden kattavuuden johdosta voimme muodostaa tutkimuksemme tarkoituksiin käsityksen sääntelyn kohteilleen aiheuttamien kustannusten arvioinnin kontekstista eli kokonaisyhteyksistä Suomessa. Suhteessa oikeusministeriön ohjeissaan luonnehtimiin kokonaisyhteyksiin yrityksille sääntelyn johdosta aiheutuvien kustannusten laskennan ja arvioinnin ala on kapea käsittäessään vain suppean osan sääntelyn ennakoiduista vaikutuksista.

Tarkastelua voidaan tarkentaa avaamalla sitä laajaa mutta oikeusministeriön ohjeissa luonnehdittua suppeampaa kenttää, joka koostuu sääntelyn kustannuksista, sääntelystä aiheutuvista taloudellisista hyödyistä sekä sääntelyllä tavoitelluista perimmäisistä vaikutuksista (Kuvio 1). Tutkimamme sääntelyvaikutusten laskennan ja arvioinnin maksimaalinen ala koostuu varsin kapeasti rajoitetusta osasta Kuviossa 1. mainittuja eriä. Luonnehdimme näiden erien systematiikkaa Taulukossa 1.
Saamme vastauksen ensimmäiseen tutkimuskysymykseemme siitä, millaisen kontekstin sääntelyvaikutusten arviointi kokonaisuudessaan muodostaa sääntelyn kohteilleen aiheuttamien kustannusten laskennalle ja arvioinnille. Kontekstiinsa nähden jälkimmäinen laskenta ja arviointi muodostaa suppean ja suorastaan kapeasti rajatuvan erityisalueen.

Voimmeko hyväksyä ensimmäisen tutkimushypoteesimme siitä, että sääntelyvaikutusten arviointi kokonaisuudessaan edustaisi soveliaisuuden instituutiologiikkaa (logic of appropriateness) pikemmin kuin välineellis-rationaalista seurausvaikutusten instituutiologiikkaa (logic of consequences)? Suomessa voimassa olevat lainsäädännön vaikutusarvioinnin ohjeet (OM 2007) ovat mallikelpoisen laajat, mutta ohjeiden noudattamisaste on jäänyt alhaiseksi (Pakarinen ym. 2010, Rantala 2011). Useimmista hallituksen esityksistä on turha etsiä näyttöperusteisia selvityksiä siitä, miten esitysten nojalla voimaan saatettavan sääntelyn ennakoidaan vaikuttavan. Vaikka ohjeet ovat voimassa, soveliaisuuden logiikasta todistaa myös se, että sovelluskäytännössä ohjeet on voitu jättää noudattamatta ilman, että ohjeista piittaamattomiin juuri kohdistuisi kielteisiä sanktioita. Voimme hyväksyä hypoteesin.

\section{Kansainväliset vaikutteet sääntelyn kohteilleen aiheuttamien kustannusten laskennassa ja arvioinnissa}

Tietyt maat ovat muodostuneet keskeisiksi kansainvälisiksi vaikutelähteiksi sääntelyn kohteilleen aiheuttamien kustannusten laskennassa ja arvioinnissa. Suomen kannalta keskeisimmät noista maista ovat vakiintunut EU-maa Saksa, EU:ssa pitkään erityiskohtelun saanut ja EU:sta Brexitin myötä eroava Iso-Britannia sekä Euroopan ulkopuolisista maista Kanada (TEM 2017, us. kohdin, Tuominen-Thuesen ym. 2018. s. 31-32 ja muissa kohdin). Tarkasteltakoon lisäksi Ranskaa tarkasteluperspektiivin terävöittämiseksi (Tuominen-Thuesen ym. 2018, s. 3334 ja muissa kohdin). Saksasta tarkasteluun otetaan yhden sijasta kaksi laskennan ja arvioinnin tapaa, joista vanhempi tarjoaa ymmärtämisperustaa varsinaisimmin tarkastellulle tavalle. Kunkin maan olosuhteita tarkastellaan kolmen pääteeman kautta yhdeksällä asiaulottuvuudella (Taulukko 2.). 


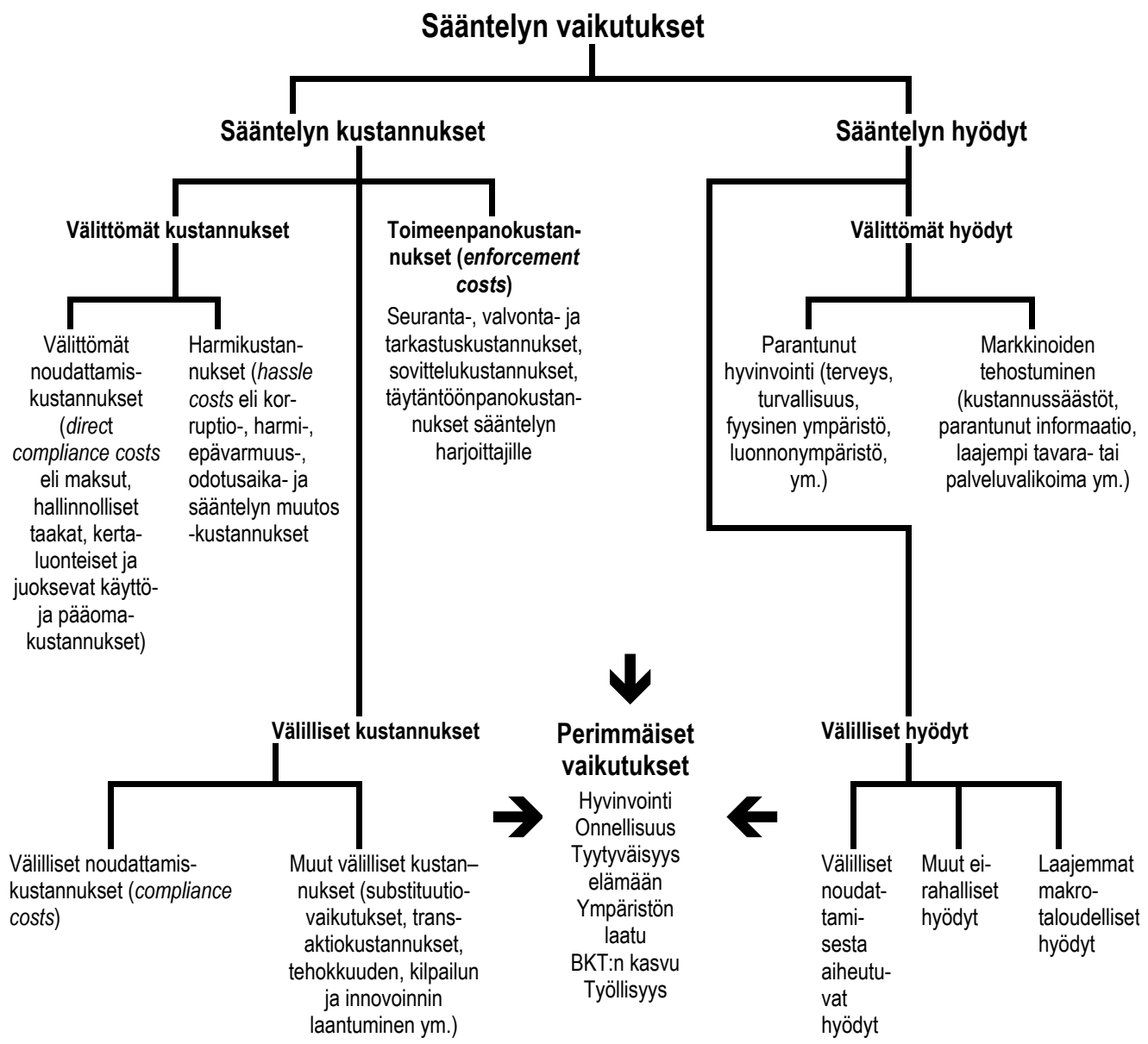

Kuvio 1. Sääntelyn kustannukset, hyödyt ja perimmäiset vaikutukset (Tuominen-Thuesen ym. 20187, 26, Rendan ym. 2013 esitystä mukaillen).

Tarkasteltujen käytäntöjen yhteisiin piirteisiin kuuluu kiinnostus siihen, miten sääntelyn purkaminen vähentää kustannuksia suhteessa uudesta sääntelystä tai sääntelyn muutoksista aiheutuviin kustannusten lisäyksiin. Tavoitteena voi olla esimerkiksi 100-prosenttinen vähennys (one-in, one-out, yksi sisään, yksi ulos) mutta jopa 300-prosenttinen supistaminen (one-in, three-out, yksi sisään, kolme ulos), kuten IsossaBritanniassa siinä vaiheessa jolloin sikäläiset käytännöt olivat esikuvina aihepiirin kehittelylle Suomessa (ks. TEM 2017, us. kohdin). Toinen yhteinen piirre on se, että kussakin käytännössä jätetään laskematta harmikustannukset (hassle costs) sekä sääntelyn kohteilta perityt maksut. Keskeisimmät eroavuuuksista koskevat laskettavia kustannuslajeja sekä laskennan kohdetahoja. Ranskassa sekä kustannuslajien että kohdetahojen valikoima on laajin, Kanadassa suppein. Saksan Büreaukratiebremse-käytäntö sijoittuu sisällöltään lähelle Ranskan käytäntöä, joskin vain Ranskassa lasketaan kustannus-hyötyanalyysin tapaan sääntelyn kustannusten ohella myös sääntelyn hyötyjä sekä kustannuksia sääntelyn harjoittajille. Ison-Britannian käytännöllä on yhtymäkohtia Kanadan käytännön kanssa, joskin Britanniassa kustannuslaskennan ala on ollut laajempi myös sisällöllisten noudattamis- 
Taulukko 1. Sääntelystä aiheutuvien välittömien kustannusten systematiikka (Tuominen-Thuesen ym. 2018, us. kohdin).

\begin{tabular}{llll}
\hline Kustannuslajit & Mistä aiheutuu? & $\begin{array}{l}\text { Miten } \\
\text { laskettavissa? }\end{array}$ & $\begin{array}{l}\text { Lasketaanko } \\
\text { käytännössä? }\end{array}$ \\
\hline 1. Sääntelyn toimeenpanokustannukset & $\begin{array}{l}\text { Sääntelytehtävistä } \\
\text { sen harjoittajille }\end{array}$ & Verrattain helposti & $\begin{array}{l}\text { Kenties jätetään } \\
\text { laskematta }\end{array}$
\end{tabular}

2. Sääntelyn kohteilleen aiheuttamat välittömät kustannukset (direct costs)

2.1. Harmikustannukset (hassle costs)

Esim. odotusajoista, viranomaispäätösten epävarmuudesta, sääntelyn perusteiden muutoksista

2.2. Välittömät noudattamiskustannukset (direct compliance costs)

2.2.1. Sääntelyn kohteilta perityt maksut

\subsubsection{Hallinnolliset taakat} (administrative burdens)

\subsubsection{Kertaluonteiset} hallinnolliset taakat

2.2.2.2. Juoksevat hallinnolliset taakat

2.2.3. Sisällölliset noudattamiskustannukset (substantive compliance costs) lainsäätäjän tahdon mukaisten sääntelyn tarkoitusperien toteutuessa
Esimerkiksi lupa- ja tarkastusmaksuista

Sääntelyn kohteiden informointi-velvollisuuksista sääntelyn harjoittajille

Ks. 2.2.2., sääntelyn tullessa voimaan

Ks. 2.2.2., sääntelyn ollessa voimassa Sääntelyn edellyttämistä sen kohteiden käyttäytymisen muutoksista

\author{
Vaikeuksin ja jopa Käytännön \\ suurin vaikeuksin sovelluksissa \\ jätetään kenties \\ laskematta
}

Vaikeuksitta tiedossa

Ks. 2.2.2.1. ja 2.2.2.2.

Verrattain pienin vaikeuksin

Verrattain pienin vaikeuksin

Äärivaihtoehtoi-

na vain suurin vaikeuksin tai toisaalta verrattain helposti
Jätetään laskematta etenkin, jos rinnastetaan veroihin

Lasketaan; voidaan korottaa henkilösivuja yleiskustannuskertoimilla

Todennäköisesti lasketaan

Ehdottomasti lasketaan Lasketaan kenties vain valikoitujen huomattavien sääntelyn muutosten yhteydessä kustannusten voidessa periaatteessa muodostua laskennan kohteeksi.

Tutkittujen laskenta- ja arviointikäytäntöjen aihepiirissä jäljittelyn (emulation) tavalliseksi kohteeksi on muodostunut kustakin käytännöstä osan muodostava sääntelyvaikutusten laskennan ja arvioinnin standardikustannusmetodi (Standard Cost Method, SCM, Coletti 2016). Kun SCM:ia sovelletaan, sääntelystä sen kohteissa aiheuttamalla työajalle lasketaan tehtävähierarkian eri tasot huomioon ottaen tuntihintastandardit. Noiden standardien mukaisilla rahamäärillä kerrotaan kullakin tehtävähierarkian tasolla sääntelystä aiheutuvat työtunnit kussakin sääntelyn kohteista. Saadut kustannukset kerrotaan monissa joskaan ei kaikissa sovelluksissa henkilösivukustannus- ja yleiskustannuskertoimilla. Lopuksi lasketaan yhteen kustannukset sääntelyn koko kohdejoukossa. SCM:n varhaisimpana soveltajamaana pidetään yleisesti Alankomaita. Metodi on paljolti levinnyt monikansallisen epävirallisen standardikustannusverkoston Standard Cost Networkin vauhdittamana (SCM Network, ei päiväystä) OECD:nkin edistäessä leviämistä.

Suomessa on ollut tavallista esittää velvoittavina OECD:n Suomea koskevia suosituksia silloinkin, kun niiden alkulähteet sijaitsevat maassamme, tai yhtä vähän sitovia EU:n toimielinten esittämiä kriittisiä maatamme koskevia lausumia (Alasuutari \& Rasimus 2009). Sanojen, termien ja käsitteiden sivumerkityksiin saattaa myös rakentua tosiasiallista velvoittavuutta, kuten nimikkeeseen "sääntelytaakka" (Rantala ym. 2018 , us. kohdin). Teema saattaa sivumerkitystensä tähden johtaa asiaan perehtymättömän olettamaan, että sääntelystä aiheutuisi vakavasti vahingollisia seurauksia. Jos yksipuoliset 
Taulukko 2. Sääntelyn kohteilleen aiheuttamien kustannusten laskennan ja arvioinnin käytännön menettelytapoja.

\begin{tabular}{|c|c|c|c|}
\hline \multicolumn{4}{|l|}{ A. Lähtökohtia } \\
\hline & Kohteet tai painopiste & Laskettavat erät & Laskematta jätettäviä eriä \\
\hline $\begin{array}{l}\text { Saksa, lainsäädännön } \\
\text { arviointineuvosto } \\
\text { Normenkontrollrat, } \\
\text { vakiomenettely }\end{array}$ & $\begin{array}{l}\text { Yritykset, kansalaiset, } \\
\text { alemmat hallinnon } \\
\text { tasot }\end{array}$ & Juoksevat hallinnolliset taakat & $\begin{array}{l}\text { Sääntelyn kohteilta } \\
\text { perittävät maksut, } \\
\text { harmikustannukset, } \\
\text { kertaluonteiset hallinnolli- } \\
\text { set taakat }\end{array}$ \\
\hline $\begin{array}{l}\text { Saksa, } \\
\text { Büreaukratiebremse } \\
\text { eli "byrokratiajarru" } \\
\text {-menettely }\end{array}$ & $\begin{array}{l}\text { Yritykset, kansalaiset, } \\
\text { alemmat hallinnon } \\
\text { tasot }\end{array}$ & $\begin{array}{l}\text { Juoksevat ja kertaluonteiset } \\
\text { hallinnolliset taakat } \\
\text { Valikoidut sisällölliset } \\
\text { noudattamiskustannukset }\end{array}$ & $\begin{array}{l}\text { Sääntelyn kohteilta } \\
\text { perittävät maksut, } \\
\text { harmikustannukset }\end{array}$ \\
\hline Ranska & $\begin{array}{l}\text { Yritykset, kansalaiset, } \\
\text { kansalaisjärjestöt, } \\
\text { alemmat hallinnon } \\
\text { tasot, välillinen } \\
\text { julkinen hallinto, } \\
\text { sääntelyn harjoittajat }\end{array}$ & $\begin{array}{l}\text { Sääntelyllä aikaansaadut } \\
\text { hyödyt } \\
\text { Juoksevat ja kertaluonteiset } \\
\text { hallinnolliset taakat } \\
\text { Valikoidut sisällölliset } \\
\text { noudattamiskustannukset } \\
\text { Kustannukset sääntelyn } \\
\text { harjoittajille }\end{array}$ & $\begin{array}{l}\text { Sääntelyn kohteilta } \\
\text { perittävät maksut, } \\
\text { harmikustannukset }\end{array}$ \\
\hline Iso-Britannia & Yritykset & $\begin{array}{l}\text { Erillistarkasteluna sääntelyn } \\
\text { hyödyt sen kohteille } \\
\text { Juoksevat ja kertaluonteiset } \\
\text { hallinnolliset taakat } \\
\text { Sisällölliset noudattamis- } \\
\text { kustannukset, lähinnä } \\
\text { valikoiden }\end{array}$ & $\begin{array}{l}\text { Sääntelyn kohteilta } \\
\text { perittävät maksut, } \\
\text { harmikustannukset }\end{array}$ \\
\hline Kanada & Yritykset & $\begin{array}{l}\text { Juoksevat ja kertaluonteiset } \\
\text { hallinnolliset taakat } \\
\text { Pk-yritystoimintaa koskevia } \\
\text { erityismenettelyjä }\end{array}$ & $\begin{array}{l}\text { Sääntelyn kohteilta } \\
\text { perittävät maksut, } \\
\text { harmikustannukset, } \\
\text { kustannuksiltaan vähäiset } \\
\text { sääntelyn muutokset, } \\
\text { sääntelyn sisällölliset } \\
\text { noudattamiskustannukset }\end{array}$ \\
\hline \multicolumn{4}{|l|}{ B. Laskentamenettely } \\
\hline & $\begin{array}{l}\text { Kustannuslisäysten } \\
\text { kompensointiaste } \\
\text { kustannuksia } \\
\text { vähentämällä } \\
\text { norminpurkutoimin }\end{array}$ & $\begin{array}{l}\text { Kustannuslisäysten ja } \\
\text { kustannusten vähennysten } \\
\text { taseen ylläpito }\end{array}$ & $\begin{array}{l}\text { Tasoituskausi ja } \\
\text { tasoituksen ala }\end{array}$ \\
\hline $\begin{array}{l}\text { Saksa, } \\
\text { Normenkontrollrat, } \\
\text { vakiomenettely }\end{array}$ & Ei kompensointia & Ei sovelleta & Ei sovelleta \\
\hline $\begin{array}{l}\text { Saksa, } \\
\text { Büreaukratiebremse }\end{array}$ & 100 \%, "yksi yhdestä" & Vuosittain & $\begin{array}{l}\text { Seurattu kustannus- } \\
\text { vähennysten enemmyyttä } \\
\text { suhteessa kustannus- } \\
\text { lisäyksiin kolmessa } \\
\text { ryhmässä: yritykset, } \\
\text { kansalaiset, alemmat } \\
\text { hallinnon tasot }\end{array}$ \\
\hline
\end{tabular}




\begin{tabular}{|c|c|c|c|}
\hline Ranska & 100 \%, "yksi yhdestä" & $36 \mathrm{kk}$ & $\begin{array}{l}36 \text { kk, sääntelyn } \\
\text { kohderyhmittäin }\end{array}$ \\
\hline Iso-Britannia & $\begin{array}{l}300 \%, \text { "kolme yh- } \\
\text { destä" } \\
\text { (Aikaisemmin } 200 \% \text { ja } \\
\text { sitä ennen } 100 \% \text {; tässä } \\
\text { tarkastelun aikakau- } \\
\text { den jälkeen on oltu } \\
\text { palaamassa lähinnä yksi } \\
\text { yhdestä -periaatteeseen) }\end{array}$ & 3-5 vuotta & $\begin{array}{l}\text { Informointi uusista } \\
\text { sääntelytoimista } \\
\text { puolivuotiskausittain } \\
\text { Seuranta 3-5 vuoden } \\
\text { aikavälein ministeriöiden } \\
\text { hallinnonaloittain }\end{array}$ \\
\hline Kanada & $\begin{array}{l}100 \text { \%, yksi yhdestä; } \\
\text { lisäksi kumottava sää- } \\
\text { dös, jos annetaan uusi } \\
\text { säädös }\end{array}$ & $24 \mathrm{kk}$ & $\begin{array}{l}\text { Ministeriöiden } \\
\text { hallinnonaloittain }\end{array}$ \\
\hline \multicolumn{4}{|l|}{ C. Toimeenpano } \\
\hline & $\begin{array}{l}\text { Laskentatulosten var- } \\
\text { mistaminen lausunto- } \\
\text { menettelyin }\end{array}$ & $\begin{array}{l}\text { Laskentatulosten varmistami- } \\
\text { nen sidosryhmäpaneelein }\end{array}$ & Vastuutaho tai hallinnonala \\
\hline $\begin{array}{l}\text { Saksa, } \\
\text { Normenkontrollrat, } \\
\text { vakiomenettely }\end{array}$ & Kyllä & Ei suoranaisesti & Liittokanslerin kanslia \\
\hline $\begin{array}{l}\text { Saksa, } \\
\text { Büreaukratiebremse }\end{array}$ & Kyllä & Ei suoranaisesti & Liittokanslerin kanslia \\
\hline Ranska & $\begin{array}{l}\text { Ei tarkoin tiedossa, } \\
\text { alustavan käsityksen } \\
\text { mukaan ei }\end{array}$ & $\begin{array}{l}\text { Ei tarkoin tiedossa, alustavan } \\
\text { käsityksen mukaan ei }\end{array}$ & $\begin{array}{l}\text { Pääministerin alainen } \\
\text { hallinto }\end{array}$ \\
\hline Iso-Britannia & Ei suoranaisesti & Kyllä & $\begin{array}{l}\text { Department for Business, } \\
\text { Energy and Industrial } \\
\text { Strategy }\end{array}$ \\
\hline Kanada & Kyllä & $\mathrm{Ei}$ & Valtiovarainministeriö \\
\hline
\end{tabular}

Lähteet: Deutschland 2015, 2017, France ei painovuotta, 2014a-c, 2015, 2017, UK 2015, 2017, Canada 2012a, b, 2015.

tähdennykset toistumistaan toistuvat, asioihin vähemmän perehtyneet saattavat alkaa uskoa, että arvostelussa on perää. KRIMO-johtoisessa hankkeessa (Rantala ym. 2018, us. kohdin) ydinkäsite "sääntelytaakka" havaittiin monin tavoin epämääräiseksi ja selventämistä vaativaksi. Eteneminen iskusanojen tuella on kyseenalaista (Pollitt \& Hupe 2011) - mutta poliittisessa, hallinnollisessa ja yritysmaailman käytännössä tavallista.

Institutionaalisen jatkuvuuden voima on ollut huomattava sääntelyn yrityksille aiheuttamien kustannusten laskennan ja arvioinnin piirissä. Tarkastelluista maakohtaisista käytännöistä kuhunkin on rakennettu sisään sääntelyvaikutusten laskennan ja arvioinnin standardikustan- nusmetodi. Tavallista on ollut se, että on argumentoitu standardikustannusmetodiin viitaten silloinkin, kun laskenta ja arviointi on kohdistunut muihinkin kustannuseriin kuin metodin soveltamisalueeseen, hallinnollisiin taakkoihin (administrative burdens). Seurauksiin standardikustannusmetodin painottumisesta kuuluu se, että sellaiset metodit kuin kustannus-hyötyanalyysi ja sen supistettu muoto kustannus-vaikuttavuusanalyysi ovat jääneet Euroopassa harvinaisiksi sääntelyvaikutusten arviointikäytännöissä toisin kuin Yhdysvalloissa (Tuominen-Thuesen ym. 2018, s. 25-27 ja muissa kohdin, Rantala ym. 2018, s. 46-47 ja muissa kohdin). Ranska tosin muodostaa poikkeuksen (Taulukko 2.). 
Näyttöjä on esitetty edellä toisen tutkimushypoteesin koettelemiseksi. Hypoteesi voidaan pysyttää voimassa.

\section{Sääntelyn yrityksille aiheuttamien kustannusten laskenta ja arviointi Suomessa}

Suomessa arvioitiin 2010-luvun alkupuolella yrityksille sääntelyn johdosta aiheutuvien hallinnollisten taakkojen suuruutta (Deloitte 2012) sekä puntaroitiin kokonaistaloudellisia seurauksia siitä, jos yrityksille aiheutuvia hallinnollisia taakkoja vähennettäisiin tietty määrä (VATT 2012). Teknisesti vaivatonta on ollut jatkaa pyrkimyksiä mukauttamalla ulkomaisia esikuvia (Taulukko 2.) laskentamallin laatimiseksi sääntelystä yrityksille aiheutuvien kustannusten laskentaan ja arviointiin (TEM 2017, ks. myös Tuominen-Thuesen ym. 2018). TEM:in mallin juuret juontuvat poliittisesta puntaroinnista syyskesällä 2016, ja mallin ensimmäinen muunnelma laadittiin TEM:issä keväällä 2017. Mallin ensimmäinen julkistus toteutui joulukuussa 2017 (TEM 2017) juuri ennen kuin mallin kahta pilottia TEM:issä ja MMM:ssä koskevaa seurantaa harjoittanut valtioneuvoston TEAS- eli tutkimus- ja kehityshanke valmistui (Tuominen-Thuesen ym. 2018). TEM:in malli saavutti keväällä 2018 kiteytetymmän kokeilun vaiheen, jonka tuloksista haluttiin asettaa riippumaan se, annetaanko mallin soveltamisesta ohjeet yrityksiiin vaikuttavan lainsäädännön valmistelu. Kun kehittämistyön tilanne tarkistettiin tätä artikkelia varten vuosien 2018 ja 2019 vaihteessa, osoittautui, että mallin kokeilu jatkui edelleen TEM:in lainsäädäntötyöhön kytkettynä (Mähönen 2019). Maan hallituksen välillä vaihduttua asia oli kesken ainakin vielä lokakuussa 2019.

Suomessa kehitetyssä yrityksille sääntelystä aiheutuvien tiettyjen kustannusten laskennan ja arvioinnin sovelluksessa (TEM 2017; Taulukko 3.) lasketaan vertailumaista Ison-Britannian ja Kanadan tapaan määrättyjä niistä kustannuksista, joita sääntely aiheuttaa yrityksille. Toisin kuin Ranskassa ja Saksassa, suomalaisessa sovelluksessa ei lasketa sääntelyn kustannuksia kansalaisille eikä alemmille hallinnon tasoille eli Suomessa lähinnä kunnille. Suomalainen sovellus muistuttaa muita tutkittuja kansallisia sovelluksia paitsi Ranskan sovellusta siten, etteivät sääntelyn hyödyt ole laskennan kohteena. Suomalainen sovellus vastaa Kanadan ja Saksan sovelluksia sikäli, etteivät yrityksiinkään sääntelyn ansioista kohdistuvat hyödyt ole laskennan ja arvioinnin kohteina. Monessa suhteessa Kanadan sovellusta muistuttava suomalainen sovellus on laskettavien kustannusten alaltaan kuitenkin laajempi. Samaan tapaan kuin IsossaBritanniassa, Ranskassa ja toisessa tutkituista Saksan malleista laskenta ja arviointi voivat Suomessa periaatteessa kohdistua myös sääntelyn yrityksille aiheuttamiin sisällöllisiin noudattamiskustannuksiin. Suomalaisen sovelluksen laajaa alaa korostaa myös se, ettei sovelluksen piiristä ole periaatteessa jätetty pois sääntelyn kohteilta sääntelyn yhteydessä perittäviä maksuja, jotka vertailumaissa veroihin rinnastettuina jätetään laskematta.

Välineellinen rationaalisuus tavoitteiden, keinojen ja sivuvaikutusten keskinäisine suhteuttamisineen, jollaista määrällinen laskenta ja arviointi edustavat, ei yksistään saa aikaan ensimmäistäkään myönteistä vaikutusta (Porter 1996). Tuollaisia vaikutuksia voi syntyä vain mikäli laskennan ja arvioinnin konteksti eli kokonaisyhteydet ovat otolliset. Vaikutusten syntyminen riippuu siitä, onko laskenta ja arviointi relevanttia sekä suhteessa sen kohteisiin että laskentaja arviointitulosten käyttöön ja missä määrin käyttö vaikuttaa politiikkatoimia ja lainvalmistelua parantavasti. Kontekstiin suhteuttamaton välineellisesti rationaalinen laskenta ja arviointi jäävät kvantifikaation suotavuutta propagoivaksi "uskomushoitoihin" rinnastuvaksi rationalisoiduksi myytiksi.

Tässä artikkelissa on luonnehdittu sääntelyn yrityksille aiheuttamien kustannusten laskennan ja arvioinnin kontekstia Suomessa viitaten virallisiin ohjeisiin säädösehdotusten vaikutusten arvioinnista (OM 2007). Samalla on kiinnitetty huomiota tutkimusnäyttöihin ohjeiden alhaisesta noudattamisasteesta (Pakarinen ym. 2010, Rantala 2011). Suomalainen sovellus sääntelystä yrityksille aiheutuvien määrättyjen kustannusten laskemiseksi ja arvioimiseksi jää neo-institutionalistiselta kannalta rationalisoiduksi myytiksi, ellei sovelluksen toimeenpanoa tueta voimassa olevien säädösehdotusten vaikutusarvioinnin ohjeiden (OM 2007) oleellisesti vahvistetulla toimeenpanolla. Siten menetellen 
Taulukko 3. Sääntelyn yrityksille aiheuttamien kustannusten laskennan ja arvioinnin ala suomalaisessa sovelluksessa (TEM 2017) suhteessa vertailumaihin (ks. myös Taulukko 2.).

\begin{tabular}{|c|c|c|}
\hline Kustannuslajit & $\begin{array}{l}\text { Kanta laskemiseen } \\
\text { suomalaisessa sovelluksessa } \\
\text { (TEM 2017) }\end{array}$ & $\begin{array}{l}\text { Suomalainen sovellus suhteessa } \\
\text { vertailumaihin (Taulukko 2.) }\end{array}$ \\
\hline 1. Sääntelyn toimeenpanokustannukset & Ei lasketa & $\begin{array}{l}\text { Rajaus Suomessa kuten Saksassa, } \\
\text { Isossa-Britanniassa ja Kanadassa, } \\
\text { mutta ahtaampi kuin Ranskassa }\end{array}$ \\
\hline $\begin{array}{l}\text { 2. Sääntelyn kohteille aiheutuvat } \\
\text { välittömät kustannukset (direct costs) }\end{array}$ & Ks. 2.1.-2.3. alakohtineen & Ks. 2.1.-2.3. alakohtineen \\
\hline $\begin{array}{l}\text { 2.1. Harmikustannukset (hassle } \\
\text { costs) }\end{array}$ & $\begin{array}{l}\text { Periaatteessa ei jätetä } \\
\text { laskematta, mutta käytännössä } \\
\text { tuskin lasketaan ainakaan } \\
\text { mallin soveltamisen } \\
\text { alkuvaiheissa }\end{array}$ & $\begin{array}{l}\text { Periaatteessa toisin mutta ainakin } \\
\text { alkuvaiheen käytännössä samoin } \\
\text { kuin neljässä vertailumaassa }\end{array}$ \\
\hline $\begin{array}{l}\text { 2.2. Välittömät } \\
\text { noudattamiskustannukset } \\
\text { (direct compliance costs) }\end{array}$ & Ks. 2.2.1.-2.2.2. alakohtineen & Ks. 2.2.1.-2.2.2. alakohtineen \\
\hline $\begin{array}{l}\text { 2.2.1. Sääntelyn kohteilta perityt } \\
\text { maksut }\end{array}$ & Tarkoituksena laskea & Toisin kuin vertailumaissa \\
\hline $\begin{array}{l}\text { 2.2.2. Hallinnolliset taakat } \\
\text { (administrative burdens) }\end{array}$ & $\begin{array}{l}\text { Korotetaan henkilösivu- ja } \\
\text { yleiskustannuskertoimilla }\end{array}$ & $\begin{array}{l}\text { Ei oleellisesti poikkea useimmista } \\
\text { vertailumaista }\end{array}$ \\
\hline $\begin{array}{l}\text { 2.2.2.1. Kertaluonteiset } \\
\text { hallinnolliset taakat }\end{array}$ & Tarkoituksena laskea & Kuten vertailumaissa \\
\hline $\begin{array}{l}\text { 2.2.2.2. Juoksevat hallinnolliset } \\
\text { taakat }\end{array}$ & Tarkoituksena laskea & Kuten useimmissa vertailumaissa \\
\hline $\begin{array}{l}\text { 2.3. Sisällölliset noudattamis-- } \\
\text { kustannukset (substantive } \\
\text { compliance costs) }\end{array}$ & $\begin{array}{l}\text { Ei periaatteessa jätetä } \\
\text { laskematta, mutta käytäntö } \\
\text { osoittaa, lasketaanko } \\
\text { valikoiden kuten } \\
\text { yhteiskunnallisesti tärkeimmissä } \\
\text { ja yritysvaikutuksiltaan } \\
\text { suurimmissa lainsäädäntö- } \\
\text { hankkeissa }\end{array}$ & $\begin{array}{l}\text { Toisin kuin Kanadassa, laajemmin } \\
\text { kuin Saksassa, vastaten lähinnä } \\
\text { Isoa-Britanniaa ja Ranskaa }\end{array}$ \\
\hline 3. Sääntelystä aiheutuvat hyödyt & Ks. hyötyjen alalajien kohdalla & Ks. hyötyjen alalajien kohdalla \\
\hline 3.1. Hyödyt sääntelyn kohteille & Ei lasketa & $\begin{array}{l}\text { Ei lasketa, toisin kuin Ranskassa ja } \\
\text { Isossa-Britanniassa }\end{array}$ \\
\hline $\begin{array}{l}\text { 3.2. Muut kuten yhteiskunta- } \\
\text { taloudelliset hyödyt }\end{array}$ & Ei lasketa & Ei lasketa, toisin kuin Ranskassa \\
\hline
\end{tabular}

voitaisiin ottaa huomioon sääntelystä muillekin tahoille kuin yrityksille aiheutuvat kustannukset, sääntelyn yhteiskunnalliset kustannukset, sääntelyn hyödyt sen eri kohteille, sääntelyn yhteiskunnalliset hyödyt sekä sääntelyn riskit ja toissijaiset vaikutukset (OM 2007). Sääntelyn yrityksille aiheuttamien tiettyjen kustannusten laskenta ja arviointi (TEM 2017) on siksi vahvasti perustelua sovittaa yhteen yleisen sääntelyvaikutusten arvioinnin kanssa laadittaessa niitä ohjeita, jotka edellisestä arvioinnista kenties annetaan (TEM 2017, us. kohdin, TuominenThuesen ym. 2018, s. 11, osa 5, s. 5).

Ennakkoarviointi ei yksinään riitä sääntelystä yrityksille aiheutuneiden kustannusten selvittämiseksi. Niin toivottavaa kuin olisikin, että jokainen päätös pantaisiin toimeen päätetyllä tavalla eikä toimeenpanossa esiintyisi alueellisia eikä muita poikkeamia, ihannetilasta jäädään usein kauas (Pressman \& Wildavsky 1973, Brunsson 1989). Mikäli esiintyy uskomuksia siihen, että päätöksenteko ja toimeenpano poik- 
keuksetta johtaisivat aiottuihin tuloksiin, nuokin uskomukset muodostavat rationalisoidun myytin. Sääntelyvaikutusten arvioinnin piirissä onkin korostettu jälkikäteistä arviointia (Tala 2018), jollaista suomalainen sovellus sääntelyn yrityksille aiheuttamien kustannusten laskemiseksi ja arvioimiseksi tarvitsee kipeästi tuekseen.

Suomalainen sovellus sääntelyn yrityksille aiheuttamien kustannusten laskemiseksi ja arvioimiseksi (TEM 2017) asettaa myös teknisiä haasteita (ks. Tuominen-Thuesen ym. 2018, us. kohdin). Renda tutkijakumppaineen tarjoaa runsaasti näyttöä siitä, että sääntelyvaikutusten arviointikäytäntöjen teknisiin perusongelmiin lukeutuvat vaikeudet taata laskenta- ja arviointimallien ja -metodien syöttötietojen laatu edes alustavasti (Renda ym. 2013, us. kohdin tarkastelun jakautuessa metodeittain). Sellaiset Suomessa ja muualla vakiintuneet käytännöt kuin lausuntomenettelyt lainsäädäntöehdotuksista eivät yleisen luonteensa vuoksi kenties riitä laadunvarmistukseen. Ellei syöttötietojen laatua varmisteta, käsitykset laadittujen laskemien ja arviointien laadukkuudesta jäävät rationalisoiduksi myytiksi. Laadunvarmistusten tapoina on toisinaan sovellettu toimialakohtaisia tarkasteluja, joissa yrityksille sääntelyn johdosta aiheutuvia kustannuksia analysoidaan niin homogeenisissa olosuhteissa, että syöttötietojen laatu voidaan varmistaa. Toisen esimerkin laadunvarmistuksesta muodostavat tietyt, IsossaBritanniassa pakolliset toimialojen edustajista muodostetut asiantuntijapaneelit, joilla varmistetaan sääntelyn yrityksille aiheuttamien kustannusten laskentamallien syöttötietojen oikeellisuutta (Tuominen-Thuesen ym. 2018, s. 12).

Myös kolmannen hypoteesin koetteleminen on tarjonnut etsittyä näyttöä. Useita rationalisoituja institutionaalisia myyttejä esiintyy uhkina siihen, että rationalisointipyrkimykset vääristyvät. Myös kolmas hypoteesi voidaan pysyttää voimassa.

\section{PÄÄTELMÄT JA KESKUSTELUA}

\section{Päätelmät}

Ensimmäisen tutkimushypoteesimme nojalla tutkimme sitä kontekstia eli niitä kokonaisyhteyksiä, jotka sääntelyvaikutusten arviointi muodostaa, kun arvioidaan julkisen sääntelyn kohteilleen aiheuttamia kustannuksia. Suomessa tuota kontekstia luonnehtivat voimassa olevat säädösehdotusten vaikutusarviointiohjeet $(\mathrm{OM}$ 2007), joiden toimeenpanoasteen alhaisuudesta on tutkimusnäyttöä (Pakarinen ym. 2010, Rantala 2011). Hypoteesin koettelun nojalla kontekstia leimaa rationalistisen seurausvaikutusten logiikan (logic of consequences) asemesta pikemminkin sovinnaisääntöihin perustuva soveliaisuuden logiikka (logic of appropriateness) (March \& Olsen 2009). Tehtävänämme ei ole ollut kiinnittää huomiota vuonna 2016 toimintansa aloittaneeseen Lainsäädännön arviointineuvostoon. Katsomme kuitenkin välttämättömäksi tähdentää sitä tosiseikkaa, ettei neuvosto ole saanut aikaan oleellista muutosta tutkimamme kahden logiikan suhteisiin. Neuvosto on vain neuvoa-antava elin ja lainsäädännön vaikutusten ennakkoarviointiohjeiden antaminen on edelleen oikeusministeriön tehtävänä. Kriittisintä on kuitenkin se, että johtopäätökset ja korjaustoimet lainsäädännön vaikutusten arviointiohjeiden paremmaksi noudattamiseksi kuuluvat valtioneuvoston vastuulle (ks. Hyytinen \& Moisio 2017).

Toisen tutkimushypoteesimme perusteella tutkimme kansainvälisiä vaikutteita, joita on kohdistunut Suomeen julkisen sääntelyn kohteilleen aiheuttamien kustannusten arvioinnin piirissä. Keskeisiksi vaikutelähteiksi osoittautuvat Iso-Britannia, Saksa ja Kanada, minkä lisäksi oli perusteltua tarkastella Ranskaa (Taulukko 2.). Hypoteesin koettelun yhteydessä tarkastelemamme vertailumaiden käytännöt viittaavat siihen, ettei sääntelyn kohteilleen ja erityisesti yrityksille aiheuttamien kustannusten laskenta ja arviointi rakennu vain välineelliselle järkiperäisyydelle (instrumental rationality). Haluttujen ratkaisujen legitimointiin tähtäävä malliesimerkkien seuraaminen on ollut tavallista etenkin silloin, kun sääntelyvaikutusten laskennan ja arvioinnin standardikustannusmalli ja -metodi rakentuvat sisään kansallisiin laskenta- ja arviointikäytäntöihin. Tarkastelemiamme kansallisia käytäntöjä luonnehtii suoranainen konvergenssi suuntaan, jota viitoittaa kuhunkin käytäntöön sisään rakennettu standardikustannusmetodi. Vääjäämättömyyden retoriikkaakaan ei ole puuttunut kansallisten laskenta- ja arviointikäytäntöjen perusteluista sellaisten ideologisten iskusanojen kuin "sääntelytaakka" 
(regulatory burden), "hallinnollinen taakka" (administrative burden) tai "yksi sisään, yksi ulos" (one-in, one-out) vahvistuksella.

Kolmatta tutkimushypoteesiamme koetellessamme tutkimme sitä, millaisin toimenpitein, perusteluin ja kokemuksin on Suomessa toimittu, jotta julkisesta sääntelystä sen kohteille aiheutuvia kustannuksia voitaisiin arvioida. Tarkastelukohteeksemme muodostuivat pyrkimykset sääntelyn yrityksille aiheuttamien määrättyjen kustannusten arvioimiseksi (Deloitte 2012, VATT 2012, TEM 2017, ks. myös Tuominen-Thuesen ym. 2018). Hypoteesin koettelun perusteella päättelimme seuraavaa. Suomalaisissa sovelluksissa on tosin kysymys pyrkimyksistä välineelliseen järkiperäistämiseen (rationalization) tavoitteita asettaen, keinot määritellen, keinoja yhdistellen tavoitteiden saavuttamiseksi sekä sivuvaikutusten kontrolloimiseksi. Rinnalla esiintyy kuitenkin myös institutionaalisia rationalisoituja myyttejä (rationalized myths, Meyer \& Rowan 1977) riskeineen siihen, että rationalisoituminen jää nimelliseksi, jää toteutumatta tai kääntyy vastakohdakseen.

Ensimmäinen rationalisoitu myytti koostuu siitä käsityksestä, että määrällinen laskenta ja sille perustuva arviointi malleineen ja metodeineen sellaisenaan saisivat aikaan myönteisiä vaikutuksia riippumatta siitä, käytetäänkö laskenta- ja arviointituloksia tarkoitetulla tavalla. Toiseksi rationalisoiduksi myytiksi jää sääntelyn yrityksille aiheuttamien kustannusten laskenta ja arviointi, ellei sitä pohjusteta laaja-alaisemmalla sääntelyvaikutusten arvioinnilla eli säädösehdotusten vaikutusarvioinnin ohjeiden (OM 2007) riittävän perusteellisella toimeenpanolla. Kolmas rationalisoitu myytti muodostuu, jos pitäydytään pelkkään sääntelystä yrityksille aiheutuvien tiettyjen kustannusten ennakkolaskentaan ja -arviointiin harjoittamatta jälkiarviointia. Neljäs rationalisoitu myytti perustuu pitäytymisestä pelkkiin laskennallisiin tuloksiin sääntelystä yrityksille aiheutuvien määrättyjen kustannusten arvioinnissa laatimatta toimialakohtaisia selvityksiä ja organisoimatta toimialakohtaisia asiantuntijapaneeleja laskentatulosten kelpoistamiseksi.

\section{Keskustelua}

Artikkelissamme olemme käyttäneet uudempia tapaustutkimusmetodologian suuntauksia sen sijaan, että olisimme hyväksyneet käsityksen tapaustutkimusten riittämättömyydestä empiiriseen yleistämiseen, josta artikkelissamme ei edes ole kysymys. Sekundaariaineiston jaottelu tapauksiksi pohjusti kolmentyyppisiä erittelyjä. Ensiksi, kontekstualisoimme tutkimiamme ilmiöitä eli suhteutimme ilmiöt niiden kokonaisyhteyksiin (1. tutkimushypoteesi). Toiseksi, realismin ja metodologisen integriteetin nimissä tähtäsimme tutkimuskohdettamme koskevien käsitysten monipuolistamiseen (2. tutkimushypoteesi). Kolmanneksi, tutkimme institutionaalisia myyttejä poikkeamina niistä rationalistista periaatteista, joiden nimissä kenties ilmoitetaan toimittavan (3. tutkimushypoteesi).

Neo-institutionalistiset teoreettiset virikkeet ohjasivat tarkastelemaan poikkeamia välineellisen rationaalisuuden periaatteista, seurausvaikutusten instituutiologiikasta sekä rationalisoinnista eli järkiperäistämisestä. Poikkeamina välineellisestä rationaalisuudesta tarkastelimme soveliaisuuden instituutiologiikkaa, legitimointiin tähtäävää malliesimerkkien seuraamista, ehdollisten seikkojen esittämistä ehdottomiksi, pitäytymistä tutusta vain rajoitetusti poikkeaviin ratkaisuihin sekä rationalisoituja myyttejä.

Näytöt poikkeamista välineellisestä rationaalisuudesta tähdentävät korjaustarpeita siellä, missä rationaalisuus vallitsee lähinnä nimellisesti. Osa tutkimustuloksistamme on suoraan muunnettavissa käytännön suosituksiksi. Tutkimamme arviointi ei ole relevanttia sellaisenaan, vaan vain mikäli se on relevanttia sekä suhteessa kohteisiinsa että sen tulosten käyttöön ja mikäli sen vaikutuksesta politiikkatointen ja lainvalmistelun laatu näyttöperusteisesti paranevat. Tutkimamme arviointi tarvitse perustakseen laaja-alaisempaa sääntelyvaikutusten arviointia sekä voimassa olevien säädösehdotusten vaikutusarvioinnin ohjeiden (OM 2007) riittävän perusteellista toimeenpanoa. Tutkimaamme ennakkoarviointia on perusteltua täydentää jälkiarvioinnilla. Tutkimamme arviointi tarvitsee täydennyksekseen avustavia menettelytapoja kuten toimialakohtaisia taustaselvityksiä ja toimialakohtaisia asiantuntijapaneeleja. 
Palautteessa artikkelimme väliversioihin meiltä toivottiin selvitystä siitä, millä, kenties radikaalilla tavalla tutkimuksemme poikkeaa arviointia ja erityisesti sääntelyvaikutusten jälkikäteistä arviointia koskevan tutkimuksen valtavirrasta. Emme kuitenkaan näe edustavamme metodologista radikalismia. Sen sijaan paikannamme tutkimuksemme annin yhdistelmääm-

\section{LÄHTEET}

Ahonen, Pertti (2015). Aspects of the institutionalization of evaluation in Finland: Basic, agency, process and change. Evaluation 21(3), 308-324.

Alapuro, Risto (1988). State and Revolution in Finland. Berkeley: University of California Press.

Alasuutari P. \& Rasimus, A. (2009). Use of the OECD in justifying policy reforms: the case of Finland. Journal of Political Power 2(1), 89-109.

Alkin Marvin C., toim. (2012) Evaluation Roots: A Wider Perspective of Theorists' Views and Influences, 2. p. Thousand Oaks, CA: SAGE.

Bengtsson, Bo \& Hertting, Nils (2014). Generalization by mechanism: Thin rationality and ideal-type analysis in case study research. Philosophy of the Social Sciences 44(6), 707-732.

Blatter, Joachim \& Haverland, Markus (2012). Designing Case Studies: Explanatory Approaches in Small-N research. Basingstoke: Palgrave Macmillan.

Brunsson, Nils (1989). The Organization of Hypocrisy: Talk, Decisions and Action in Organizations. New York: Wiley.

Brunsson, Nils (2009). Reform as Routine: Organizational Change and Stability in the Modern World. Oxford: Oxford University Press.

Canada (2012a). Controlling Administrative Burden that Regulations Impose on Business: Guide for the "One-for-one" rule. Ottawa: Treasury Board.

Canada (2012b). Hardwiring Sensitivity to Small Business Impacts of Regulation: Guide for the Small Business Lens. Ottawa: Treasury Board.

Canada (2015). Red Tape Reduction Regulations. SOR 2015-202. Ottawa: Treasury Board.

Cohen, Michael D., March, James G. \& Olsen, Johan P. (1973). A garbage can model of organizational choice. Administrative Science Quarterly 17(1): 1-25.

Coletti, Paola (2016). Standard cost model. Teoksessa Dunlop, Claire A. \& Radaelli, Claudio M. (toim.), Handbook of Regulatory Impact Analysis (s. 93-107). Cheltenham: Edward Elgar.

Cyert, Richard M. \& March, James G. (1963). me tutkimusta on evaluation/on assessment in evaluation/in assessment -tutkimuksen sijaan, ratkaisuumme etsiä aineksia "on"-tutkimukseemme neo-institutionalistisen tutkimuksen valikoiduilta suunnilta sekä omaksumaamme uudempaan tulkintaan tapaustutkimusmetodologian mahdollisuuksista.

Behavioral Theory of the Firm. Oxford: Blackwell. De Francesco, Fabrizio (2013). Transnational Policy Innovation: The OECD and the Diffusion of Regulatory Impact Analysis. Colchester: ECPR Press.

Deloitte (2012). Selvitys yritysten hallinnollisen taakan kehityksestä. Helsinki: TEM.

Deutschland (2015). Bürokratiebremse: Konzeption einer One in, one out-Regel. Berlin: Bundesregierung.

Deutschland (2017). Bürokratieabbau: Bessere Rechtsetzung, Digitalisierung. Jahresbericht des Nationalen Normenkontrollrates. Berlin: Nationaler Normenkontrollrat.

Dunlop, Claire A. \& Radaelli, Claudio M. (toim.) (2016). Handbook of Regulatory Impact Analysis. Cheltenham: Edward Elgar.

Flyvbjerg, Bent (2006). Five misunderstandings about case-study research. Qualitative Inquiry 12(2), 219-245.

France (Ei painovuotta). Fiche d'impact: Project de texte reglémentaire. Ranskan hallituksen virallisia lainvalmisteluohjeita. Ei painopaikkaa eikä julkaisijatietoa.

France (2014a). Rapport d'information fait en application de larticle 145 du Règlement au nom de la mission d'information sur la simplification législative. Paris: Assemblée nationale.

France (2014b). Études d'impact. Legifrance: Le service public de la diffusion du droit. Paris: Legifrance.

France (2014c). Manuel d'aide au calcul de l'impact financier de la réglementation. FParis: Secrétariat général du gouvernment.

France (2015). Objet: Evaluation préalable et qualité $d u$ droit. No. 5817/SG, 12.10.2015. Paris: Le Premier Ministre.

France (2017). Les études d'impact des lois. Legifrance: Le service public de la diffusion du droit. Paris: Legifrance.

Fusch, Patricia I. \& Ness, Lawrence R. (2015). Are we there yet? Data saturation in qualitative research. The Qualitative Report 20(9), 1408-1416. 
George, Alexander L. \& Bennett, Andrew (2006). Case Studies and Theory Development in the Social Sciences. Cambridge, MA: MIT Pres.

Hirschman, Albert O. (1991). Rhetoric of Reaction: Perversity, Futility, Jeopardy. Cambridge, MA, Belknap Press of the Harvard University Press.

Hyytinen, A., \& Moisio, A. (2017). Lainsäädännön arviointineuvosto: Lainvalmistelun vaikutusarviointia. Kansantaloudellinen aikakauskirja 113 (2), 206-212.

Lee, Chang Kil \& Strang, David (2006). The international diffusion of public-sector downsizing: Network emulation and theory-driven learning. International Organization 60(4), 883-909.

Lodge, Martin \& Wegrich, Kai (2012). Managing Regulation: Regulatory Analysis, Politics and Policy. Houndmills: Palgrave Macmillan.

Lowndes, Vivien \& Roberts, Mark (2013). Why Institutions Matter: The New Institutionalism in Political Science. Houndmills: Palgrave Macmillan.

March, James G. \& Olsen, Johan, P. (2009). The logic of appropriateness. Arena Center for European Studies 04/09. Oslo: Arena.

Meyer, John W. \& Rowan, Brian (1977). Institutional organizations: Formal structure as myth and ceremony. American Journal of Sociology 83(2), 340-363.

Mähönen, Erno (2019). Yksi yhdestä -periaatteen kokeilu työvoima- ja elinkeinoministeriössä vuonna 2018: Kokeiluhankkeen vuosiraportti. Helsinki: TEM.

OM (2007). Säädösehdotusten vaikutusten arviointi: Ohjeet. Helsinki: Oikeusministeriö.

Pakarinen Auri, Tala, Jyrki \& Hämynen, Laura (2010), Vaikutusten arviointi vuoden 2009 hallituksen esityksissä. Oikeuspoliittisen tutkimuslaitoksen tutkimustiedonantoja 104. Helsinki: Oikeuspoliittinen tutkimuslaitos.

Pollitt, Christopher \& Hupe, Peter (2011). Talking about government. Public Management Review 13(5), 641-658.

Porter, Theodore M. (1996). Trust in Numbers: The Pursuit of Objectivity in Science and Public Life. Princeton, NJ: Princeton University Press.

Pressman, Jeffrey D. \& Wildavsky, Aaron (1973). Implementation. Berkeley: University of California Press.

Quaglia, Lucia (2019). The politics of state compliance with international 'soft law' in finance. Governance, 32(1), 45-62.

Radaelli, Claudio M. (2005). Diffusion without convergence: How political context shapes the adoption of regulatory impact assessment. Journal of European Public Policy 12(5), 924943.
Rantala, Kati (2011). Lainvalmistelun laatu hallituksen kärkihankkeissa. Oikeuspoliittisen tutkimuslaitoksen tutkimuksia 255. Helsinki: Oikeuspoliittisen tutkimuslaitos.

Rantala Kati, Ahonen, Pertti, Alasuutari, Noora, Kauppila, Jussi, Kautto, Petrus, Kuokkanen, Kanerva, Römpötti, Essi, Saarenpää, Karolina, Tala, Jyrki \& Uusikylä, Petri (2018). Eroon turhasta sääntelystä - sääntelytaakan arviointi ja vähentäminen. Helsinki: Valtioneuvoston kanslia.

Renda, Andrea, Schrefler, Lorna, Luchetta, Giacomo \& Zavatta, Roberto (2013). Assessing the Costs and Benefits of Regulation: Study for the European Commission, Secretariat General. Brussels: CEPS.

Reynolds, Arthur J. (1998). Confirmatory Program Evaluation: A Method for Strengthening Causal Inference. American Journal of Evaluation 19(2), $203-221$.

Schriewer, Jürgen (2009). "Rationalized myths" in European higher education: The construction and diffusion of the Bologna model. European Education 41(2), 31-51.

SCM Network (julkaisuvuotta ei ilmoitettu). International standard cost manual. Paris: OECD.

Silverman, David (2011). Interpreting Qualitative Data. 4. p. Los Angeles, CA: Sage.

Simon, H.A. (1947). Administrative Behavior: A Study of Decision-making Processes in Administrative Organization. 4. p. 1997. 3. p.:n suomennos Päätöksenteko ja hallinto, 1979. New York: Macmillan.

Skocpol, Theda (1979). States and Social Revolutions: A Comparative Analysis of France, Russia and China. Cambridge: Cambridge University Press.

Stark, Alastair (2019). Explaining institutional amnesia in government. Governance, 32(2), 143-158.

Tala, Jyrki (2018). Jyrki Talan vastuuosuus lainsäädännön vaikutusten jälkiarvioinnista teoksessa Rantala ym. 2018.

TEM (2017). Yksi yhdestä -kokeiluhankkeen loppuraportti. Työ- ja elinkeinoministeriön julkaisuja 45/2017. Helsinki: TEM.

Tuominen-Thuesen, Minna, Sievänen, Riikka, Ljungman, Jan, Kuusela, Hanna, Ahonen, Pertti ja Uusikylä, Petri (2018). "Yksi yhdestä" -malli osana sääntelyn kehittämistä ja arviointia. Helsinki: Valtioneuvoston kanslia.

UK (2015). Better Regulation Framework Manual. Practical Guidance for UK Government Officials. London: UK Government. 
UK (2017). Regulatory Impact Assessment Template for Government Policies. London: Department for Business, Energy \& Industrial Strategy.

Uusikylä, Petri \& Ahonen, Pertti (2015). EU-aloitteiden vaikutusten arvioinnin tehostaminen. Helsinki: Valtioneuvoston kanslia.

VATT (2012). Yritysten hallinnollisen taakan vähentämisen kokonaistaloudelliset vaikutukset. Helsinki: VATT.
Weyland, Kurt (2007). Bounded Rationality and Policy Diffusion: Social Sector Reform in Latin America. Princeton, NJ: Princeton University Press.

Yin, Robert K. (2016). Qualitative Research from Start to Finish. 2 p. New York: Guildford Press. 